\title{
Oral manifestations in a boy with X-linked reticulate pigmentary disorder
}

\author{
M Callea ${ }^{1 *}$, M Maglione $^{2}$, I Yavuz ${ }^{3}$, L Deroma $^{4}$, CE Willoughby ${ }^{5}$, G Tadini ${ }^{6}$ \\ From 5th International Conference on Ectodermal Dysplasia (ED2012) \\ Erlangen, Germany. 1-3 June 2012
}

\section{Introduction}

$\mathrm{X}$-linked reticulate pigmentary disorder (XLPDR) is a rare, multi-systemic disease with only a limited number of families described in the literature. XLPDR has a genetic origin and the gene has been mapped to Xp22p21. Dental features resemble those of hypohidrotic ectodermal dysplasia.

\section{Case report}

A 3-year-old boy was seen at the Department of Maxillo-Facial Surgery and Paediatric Dentistry of the Children's Hospital of Trieste. The multi-systemic features of XLPDR included a number of oro-dental manifestations such as misshapen teeth, scissor bite, swallowing difficulties, agenesis of the 4 permanent second premolars, taurodontism, early resorption of deciduous roots, and premature tooth eruption in general. Other important characteristics are crowding of permanent inferior tooth crowns, severe gingivitis, enamel hypoplasia and discoloration due to multiple antimicrobial treatments.

\section{Discussion}

XLPDR is a rare form of ectodermal dysplasia with multi-systemic manifestations requiring intensive medical supervision. Clinically, the oro-dental phenotype resembles that of hypohidrotic ectodermal dysplasia, but there are several novel, previously unreported features.

\section{Author details}

'Department of Maxillo-Facial Surgery and Paediatric Dentistry, Institute for Maternal and Child Health, Trieste, Italy. ${ }^{2}$ University of Trieste, Italy. ${ }^{3}$ Dicle University, Diyarbakır, Turkey. ${ }^{4}$ University Hospital Santa Maria della Misericordia, Udine, Italy. ${ }^{5}$ Queen's University Belfast, Northern Ireland, UK. ${ }^{6}$ University of Milano, Italy.

'Department of Maxillo-Facial Surgery and Paediatric Dentistry, Institute for Maternal and Child Health, Trieste, Italy

Full list of author information is available at the end of the article
Published: 25 May 2012

doi:10.1186/1746-160X-8-S1-P9

Cite this article as: Callea et al:: Oral manifestations in a boy with X-

linked reticulate pigmentary disorder. Head \& Face Medicine 2012 8(Suppl 1):P9.
Submit your next manuscript to BioMed Central and take full advantage of:

- Convenient online submission

- Thorough peer review

- No space constraints or color figure charges

- Immediate publication on acceptance

- Inclusion in PubMed, CAS, Scopus and Google Scholar

- Research which is freely available for redistribution

Submit your manuscript at www.biomedcentral.com/submit
C Biomed Central 